\title{
Leadership in the quality of hotel services in the city of Campeche, Mexico
}

\section{Liderazgo en la calidad de los servicios hoteleros de la ciudad de Campeche, México}

QUIJANO-GARCÍA, Román Alberto†, ARGUELLES-MA, Luis Alfredo, MEDINA-BLUM, Fernando and FAJARDO, Mario Javier

Universidad Autónoma de Campeche, Facultad de Contaduría y Administración. Av. Agustín Melgar S/N entre Calle 20 y Juan de la Barrera. Col. Buenavista. CP 24039.

ID $1^{\text {st }}$ Author: Román, Quijano-García / ORC ID: 0000-0001-7316-1997, Researcher ID Thomson: G-6014-2018 CVU: 485854

ID $1^{\text {st }}$ Coauthor: Luis Alfredo, Arguelles-Ma / ORC ID: 0000-0003-0315-4585, Researcher ID Thomson: S-5454-2018 CVU: 300184

ID $2^{\text {nd }}$ Coauthor: Fernando, Medina-Blum / ORC ID: 0000-0001-6532-0871, Researcher ID Thomson: M-1632-2017

ID $3^{\text {rd }}$ Coauthor: Mario Javier, Fajardo / ORC ID: 0000-0001-7021-247X, Researcher ID Thomson: S-4886-2018

DOI: $10.35429 /$ EJRP.2019.8.5.20.29

Received February 10, 2019; Accepted June 17, 2019

\begin{abstract}
The remainance and development in the market depend, among other factors, on the quality of sold products or provided services, which is a situation of concern in sectors such as tourism where globalization demands first level services, as is the case in the city of Campeche, where businessmen are investing in hotel infrastructure according to the colonial characteristics of the town. The research's objective is to identify the incidence of leadership in the quality of services under the perception of hotel managers as responsible for the operability results. This research is a descriptive type with non-experimental transversal design, with a enumerated population; the results obtained through the quality and leadership indexes indicate that, contrary to expectations, managers consider that the provided services don't have an adequate level of quality, and the design of new strategies is needed to improve the processes under the transformational leadership which must face problems with opportunity in order to innovate in the services of the market where they participate.
\end{abstract}

Quality, Leadership, MSMEs

\begin{abstract}
Resumen
Permanecer en el mercado y desarrollarse depende entre otros factores, de la calidad de los bienes vendidos o los servicios prestados, situación por demás preocupante en sectores como el turismo donde la globalización exige servicios de primer nivel, tal como ocurre en la ciudad de Campeche, donde los empresarios están invirtiendo en infraestructura hotelera acorde a las características coloniales de la localidad. Este trabajo tiene como objetivo identificar la incidencia del liderazgo en la calidad de los servicios bajo la percepción de los gerentes de los hoteles como responsables en gran medida de los resultados de la operatividad. El estudio es descriptivo con diseño no experimental transversal, con una población censada considerando su número; los resultados obtenidos a través de los índices de liderazgo y calidad señalan, contrario a lo esperado, que los gerentes consideran que los servicios otorgados no reúnen niveles adecuados de calidad, debiéndose diseñar nuevas estrategias para la mejora de los procesos bajo el liderazgo transformacional que debe enfrentar los problemas con oportunidad para innovar los servicios del mercado donde participan.
\end{abstract}

Calidad, Liderazgo, Mipymes

Citation: QUIJANO-GARCÍA, Román Alberto, ARGUELLES-MA, Luis Alfredo, MEDINA-BLUM, Fernando and FAJARDO, Mario Javier. Leadership in the quality of hotel services in the city of Campeche, Mexico. ECORFAN JournalRepublic of Peru. 2019. 5-8: 20-29.

$\dagger$ Researcher contributing first author. 


\section{Introduction}

Based on the economic information of the last planning document of the Mexican government (Six-Year Development Plan), the tourism sector is a source of wealth for Mexico, occupying the third place in the generation of foreign currency after the oil activity and the reception of remittances sent by Mexicans who work abroad mainly in the United States, therefore the promotion of tourism activity is essential for job creation and economic stability (National Development Plan, PND 2013-2018).

The government of the state of Campeche through the State Development Plan (PED 2015-2021), designed strategies and lines of action to strengthen tourism potential and thus generate jobs and economic growth along with the social welfare of the population through the ordering of the sector, promoting a greater flow of direct investment and financing by raising the competitiveness of the activity in a sustainable way. As main tourist assets, the State has the fortified city of Campeche, the only walled city in Mexico that has the UNESCO Cultural Heritage badge granted by UNESCO in 1999 as well as the Mixed Heritage (cultural and natural) ) granted to the ancient Mayan city and protected tropical forests of Calakmul since 2014. There are 16 archaeological areas open to the public where you can appreciate the Mayan culture, two site museums and 9 museum spaces (PED 20152021).

\section{Justification}

As part of the strategic objectives of the PED 2015-20021, the city of Campeche intends to position itself as a final tourist destination and not passing to other points of the Yucatan Peninsula, to pick up the sector and not depend on the oil activity that is found focused on Ciudad del Carmen, and which is going through serious operational and economic problems; In this sense, Campeche hotel MSMEs must identify their competitive advantages for their economic development.

The hotel sector needs to be integrated by organizations that know their strengths and weaknesses at the level of infrastructure and processes under the leadership style of the decision maker, to position themselves in a market that demands quality in comprehensive services for national and foreign tourism.

\section{Problem Statement}

According to the data of the National Statistical and Geographic Information System of Tourism (SNIEGT, 2019) at the end of 2018, the tourism sector generated 4,187,000 direct jobs, which represents $8.9 \%$ of the total economically active population employed, its contribution to National GDP is equal to $8.7 \%$ at the end of the third quarter of the same year.

Given the resurgence of the crisis in the oil sector that has consequences at international and national level, the strategies proposed in the economic planning documents seek to promote tourism investments of MSMEs, promoting the care and preservation of the country's cultural, historical and natural heritage (PND , 20132018).

Based on the above, studies are required that contribute to the strengthening and development of the companies that participate in this sector, to turn them into organizations that offer competitive services at international level as required by globalization.

\section{Objectives}

This study aims at the following objectives: a) Identify the quality elements in the operations of MSMEs in the hotel sector of the city of Campeche, b) Identify the leadership style present in this type of organizations and c) Establish the perception of managers regarding leadership and its impact on the quality of hotel services in the city

\section{Theoretical framework}

\section{Leadership in the tourism sector}

Turbay (2013), poses as a question in his study of leadership and organizational innovation, what are the factors that will allow organizations to survive the changes that occur in their environment and be competitive, believes that from leadership, organizations make in the face of the changing environment that modifies its structures and processes, therefore innovation is the condition to remain in the market. 
The author argues that leadership is a strategic factor for the development and maintenance of companies in the market, indicating transformational leadership as the ideal to lead the organization towards innovation, in this same sense Contreras and Barbosa (2013), consider that Leadership has strong implications for organizational change and raises the need to evolve from a type of transactional leadership (typical of stable environments) to a transformational one (instability and uncertainty are common); conceptualizing the company as a system that through self-organization manages to adapt to the unstable environments where they currently operate. Estrada (2006), proposes a leadership model for changing organizations, such as the tourism sector, based on the integrality of the organizational leader; part of the characterization of the leader, composed of the qualities, skills, and attitudes necessary to lead organizations to achieve the proposed goals. Some studies indicate that the professional capacity, the way of communicating, the commitment to the organization and the way in which the problems are solved are related to the competences and leadership performance in the organizations of the tourism sector, (Zayas 2011). According to Velázquez (2005) empathic leadership allows the design of work schemes and organizational structures, for which it is necessary to develop high levels of affinity between managers and collaborators, the result must be reflected in the innovation of the processes, the development of creativity in favor of the company, identity with the organizational culture and achieve customer satisfaction in the tourism sector.

Barreto and Azeglio (2013), formulated a study in the tourism sector of Buenos Aires, Argentina and conclude that adequate training and motivation of human resources, and group work are linked to leadership style; This is related to the professional training of the managers responsible for making decisions in the organizations participating in the project. In Mexico Díaz, Medina and de la Garza (2011), through the questionnaire called inventory of leadership practices formulated by Kouzes and Posner, evaluated whether leadership provides competitive advantage, its results indicate that it influences the quality of the services offered through the way in which it acts, solves problems, takes risks and involves employees in the future of the organization considering their opinions through open communication.

\section{Quality in SME hotel services}

Meira, and Rojas (2014), developed a bibliometric analysis on the scientific production of research related to quality in tourism services, finding that knowledge has been generated on this topic and opportunities for new research, considering that the studies developed are basically concentrated in North America, Europe and Asia, which gives an opportunity to expose the problem throughout the southern hemisphere. Foronda and García, (2009), consider that quality is a differentiator in tourist destinations, as an axis of strategy and that forces the renewal of quality plans developed by organizations, which have encouraged the application of tourism planning instruments in mature and emerging destinations; they have reinforced the cooperation networks of public and private administrations, they are a way of acting and provoking a dynamic effect in the tourism sector of Spain.

Fuentes, Hernández and Morini (2016), indicate that the quality recognized in the services influences the satisfaction obtained by the client in a different way, they could establish that the average quality of the services in the five-star hotels is high and the client does not observe a significant difference; the differences are greater in three-star hotels, where hotel managers often have little guidance on how to establish whether the experience of the service provided to the customer is satisfactory. As part of the research to diagnose the quality of lodging services, Reyes, Guzmán and Morales (2015) developed a work that allowed them to know the expectations and perceptions of tourists in Acapulco, Gro., Using the Servqual model, finding that the The best evaluated variables were human resources, with a perception above expectations, but not in the case of facilities and equipment, which allowed them to point out the need to modernize the traditional areas of the tourist destination to recover the level of competitiveness and raise hotel occupancy, which has remained stagnant in recent years, in this international reference port of Mexico. 
Ibañez (2011), made a diagnosis of the quality and competitiveness of the tourism sector in Mexico considering that the globalization of the economy intensifies competition between destinations, pointing out the need to undertake efforts to maintain the privileged position that Mexico had, who has not yet It has consolidated the culture of quality and competitiveness which originates its tendency to lag in the ranking of the main tourist destinations in the world, for which it recommends implementing programs that certify the training of personnel, granting facilities for companies and workers to obtain certifications in quality, originate truthful and up-to-date information from government institutions, improving access to information; incentivize socially responsible companies to promote the use of alternative energy and revalue the human resources of all levels, which has an impact on the image that the company, the destination and the country offer the tourist.

Guerra and Cardozo (2010) considered that the management by competences is a tool that contributes to guarantee the quality of the service in the tourist inns of Tachida Venezuela, these researchers consider the human factor as essential in the sector, therefore, they identify the need to train and train staff in a planned way, measure their performance and thus together with other elements to evaluate the service.

They proposed a tool based on competencies and variables of the Servqual, to determine the key positions, profiles for both generic and specific competencies, seeking to increase the demonstrated performance. Gutiérrez and Rubio (2009) considered the need for a change in the culture of tourism businesses and identified the human factor as a fundamental element in the management of service quality, the above when observing the increase in competition linked to the improvement of quality and its management systems, where the human factor is finally mentioned but not involved as a key piece in the development of services to achieve customer loyalty and satisfaction.

The foregoing defines as the sole evaluator of customer quality and subjectivity of their perception.

\section{Research methodology}

\section{Type of investigation}

Descriptive study because information is measured or collected on the variables analyzed, with a non-experimental cross-sectional design since data were collected at a single moment in their natural context, through questionnaires administered to the MSME managers of the hotel sector, with the purpose to describe variables and analyze their incidence. The method used for the collection of quantitative information is through fieldwork and the technique used is the survey (Hernández, Fernández and Baptista, 2016).

\section{Subjects in the study}

The population was satisfied with tourist MSMEs of the hotel sector, specifically those that do not belong to chains or franchises of the city of Campeche and whose leadership was previously studied by Quijano, Arguelles, Medina and Fajardo (2017), now addressing its incidence in the Quality of services provided. The companies identified with this specialty were 26, according to the Mexican Business System directory as of February 2, 2016. Of the 26 hotels identified, 23 agreed to participate, representing $88 \%$ of the initial universe.

\section{Instruments}

The information was obtained through the questionnaire formulated by Mul, Mercado and Ojeda (2013) who designed it to study how knowledge is managed in companies in southeastern Mexico and includes reagents related to leadership, the integration of the instrument described in Table 1. 


\begin{tabular}{|c|c|c|c|}
\hline Dimension & $\begin{array}{c}\text { Operational } \\
\text { Definition }\end{array}$ & Reagents & Proportion \\
\hline Transformational & $\begin{array}{l}\text { It consists of } \\
\text { accepting challenges } \\
\text { and risks in the search } \\
\text { to provide an } \\
\text { innovation. }\end{array}$ & $\begin{array}{r}77,78,79 \\
80,81\end{array}$ & $13.1 \%$ \\
\hline Transactional & $\begin{array}{l}\text { It is the identity of the } \\
\text { leader between what } \\
\text { is said and what is } \\
\text { done in business } \\
\text { practice, to create } \\
\text { momentum and } \\
\text { progress in the } \\
\text { organization. }\end{array}$ & $73,74,75,76$ & $10.5 \%$ \\
\hline $\begin{array}{l}\text { Problem } \\
\text { resolution }\end{array}$ & $\begin{array}{l}\text { It is the opportunity } \\
\text { and way in which } \\
\text { business obstacles } \\
\text { are faced by the } \\
\text { leader of the } \\
\text { organization. }\end{array}$ & 83,82 & $5.3 \%$ \\
\hline
\end{tabular}

Table 1 Elements of the leadership questionnaire administered to hotel managers

Source: own elaboration with data from Mul, Mercado and Ojeda (2013)

The instrument has a section that collects socio-demographic information and the manager's administrative profile, as well as the company's positioning in the market. In the case of the quality variable, the questionnaire designed by Parasuraman, Zeithaml and Berry (1985) was used. This instrument is linked to the objectives of the investigation by contributing to the identification of the expectations and perception that hotel managers have regarding the services offered by participating companies, (Table 2).

\begin{tabular}{|c|c|c|c|}
\hline Dimension & Definition & Reagents & Proportion \\
\hline Tangibility & $\begin{array}{l}\text { It is the } \\
\text { operational and } \\
\text { administrative } \\
\text { infrastructure that } \\
\text { serves as the basis } \\
\text { for the services } \\
\text { offered by the } \\
\text { organization. }\end{array}$ & $1,2,3,4$ & $22.2 \%$ \\
\hline Reliability & $\begin{array}{l}\text { These are the } \\
\text { processes } \\
\text { developed by the } \\
\text { company's } \\
\text { personnel through } \\
\text { which the services } \\
\text { are provided. }\end{array}$ & $5,6,7,8,9$ & $27.7 \%$ \\
\hline $\begin{array}{l}\text { Answer's } \\
\text { capacity }\end{array}$ & $\begin{array}{l}\text { Operations } \\
\text { carried out by the } \\
\text { organization's } \\
\text { employees in a } \\
\text { timely manner. }\end{array}$ & $10,11,12$ & $16.7 \%$ \\
\hline Warranty & $\begin{array}{l}\text { Performing } \\
\text { processes by staff } \\
\text { with attitude and } \\
\text { vocation of } \\
\text { customer service. }\end{array}$ & $13,14,15$ & $16.7 \%$ \\
\hline Empathy & $\begin{array}{l}\text { They are the } \\
\text { processes } \\
\text { developed by the } \\
\text { collaborators with } \\
\text { a sense of identity } \\
\text { towards the client. }\end{array}$ & $16,17,18$ & $16.7 \%$ \\
\hline
\end{tabular}

Table 2 Definitions of the quality questionnaire administered to hotel managers

Source: own elaboration with data from Parasuraman, Zeithaml and Berry (1985)
Both instruments consider scores assigned on a Likert scale with values ranging from 1 = Strongly disagree, $2=$ Disagree $3=$ Agree and $4=$ Strongly agree.

\section{Instrument Reliability}

The pilot test was developed with $10 \%$ of the population to adapt them to the participating population; Cronbach's alpha was determined with a value of 0.701 for leadership and 0.902 for quality. When the test is replicated, the values in general for each variable and dimension are shown in Table 3.

\begin{tabular}{|l|l|r|r|}
\hline \multicolumn{2}{|c|}{ Variable } & \multicolumn{1}{c|}{$\begin{array}{c}\text { Number } \\
\text { of items }\end{array}$} & $\begin{array}{c}\text { Cronbach's } \\
\text { alpha }\end{array}$ \\
\hline Leadership & & 11 & 0.654 \\
\hline & Transformational & 5 & 0.601 \\
\hline & Transactional & 4 & 0.624 \\
\hline & $\begin{array}{l}\text { Problem } \\
\text { resolution }\end{array}$ & 2 & 0.685 \\
\hline Quality & & 18 & 0.937 \\
\hline & Tangibility & 4 & 0.887 \\
\hline & Reliability & 5 & 0.874 \\
\hline & Answer's capacity & 3 & 0.770 \\
\hline & Warranty & 3 & 0.720 \\
\hline & Empathy & 3 & 0.535 \\
\hline
\end{tabular}

Table 3 Reliability of the leadership and quality questionnaire administered to managers

Source: own elaboration based on statistical information

It is important to note that the reliability parameter for the leadership variable and the empathy dimension in the case of quality can be considered low for certain standards; However, Kerlinger (2002) states that when an instrument does not reach an index that is considered reliable, this may be due to the insufficient amount of reagents, and an error may arise due to chance or the individual's interpretation. of the reagent.

For the particular case of the questionnaires used, these contained few questions for the variables under study; Another factor to consider in this result is that the population surveyed was only 23 people.

\section{Procedure for data collection and analysis}

Questionnaires were personally applied to hotel managers with a duration of twenty minutes each, and the data was processed through SPSS version 21 software. 


\section{Results}

The leadership questionnaire includes three dimensions and the five quality one, through the calculation of the mean and standard deviation, the closest and most distant reagents of the values assigned in the instruments were identified, being able to observe the degree of dispersion of the responses, (Table 4).

\begin{tabular}{|c|c|c|c|c|c|}
\hline Dimension & $\frac{\dot{8}}{\mathrm{E}}$ & 晋总 & 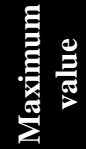 & 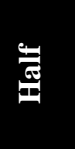 & 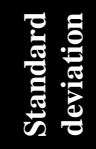 \\
\hline \multicolumn{6}{|c|}{ Variable: leadership } \\
\hline Transformational & 23 & 1 & 4 & 3.16 & 0.816 \\
\hline Transactional & 23 & 1 & 4 & 2.73 & 0.868 \\
\hline $\begin{array}{l}\text { Problem } \\
\text { resolution }\end{array}$ & 23 & 1 & 4 & 2.37 & 1.157 \\
\hline \multicolumn{6}{|l|}{ Variable Calidad } \\
\hline Tangibility & 23 & 2 & 4 & 2.94 & 2.0879 \\
\hline Reliability & 23 & 2 & 4 & 3.21 & 2.5568 \\
\hline Answer's capacity & 23 & 2 & 4 & 3.05 & 1.6693 \\
\hline Warranty & 23 & 2 & 4 & 3.31 & 1.2960 \\
\hline Empathy & 23 & 1 & 4 & 3.17 & 1.3440 \\
\hline
\end{tabular}

Table 4 Descriptive statistics of the leadership and quality variables

The table indicates the average of the values assigned by the respondents with respect to the variables studied, in no case the averages reach the highest value established, the above is corroborated with the dispersion in the responses. Source: Statistical information obtained from the survey previously determined by Quijano et al (2017). In the leadership variable, the lowest average was obtained by the dimension "problem solving" and the highest was called "transformational", which indicates that the followers understand the power system in the organization, negotiation processes are promoted with the work team and agree with the rewards scheme provided by the company, Table 5.

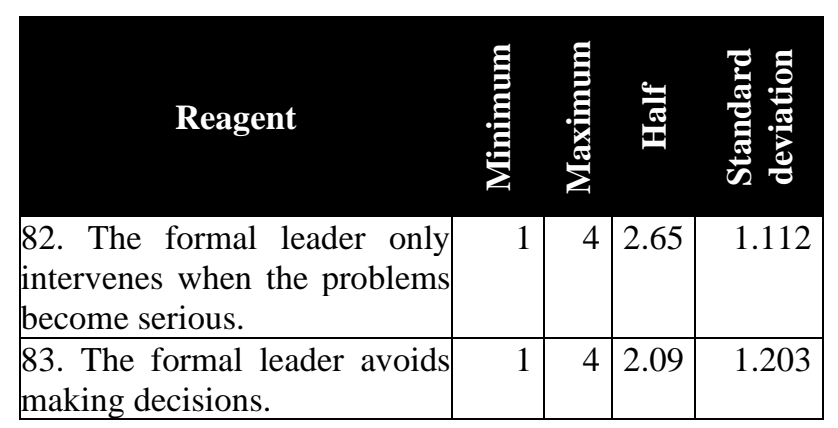

Table 5 Descriptive statistics regarding the problemsolving dimension of the leadership variable
In the case of the quality variable, none of the five dimensions obtained values close to 4 , the highest corresponds to the "guarantee" dimension, and the lowest "tangibility", which indicates that the managers of the companies consider that the personnel inspire customer trust, but facilities and infrastructure must be improved. On the other hand, "reliability" is the dimension that obtained a greater dispersion in the responses, which indicates that in most organizations, personnel need to commit more to the service policies offered by companies in terms of time and characteristics (Table 6).

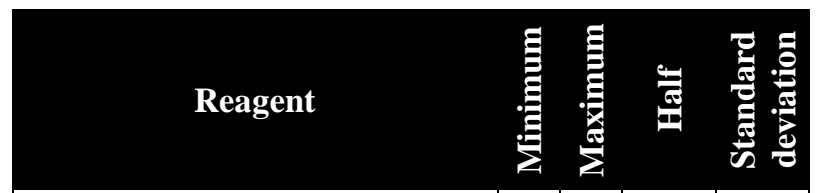

\begin{tabular}{|l|l|l|l|l|}
\hline 5. If your establishment's staff & 2 & 4 & 3.17 & .650 \\
\hline
\end{tabular} agrees to do something for a certain period of time, it complies \begin{tabular}{|lll|l|l|l|l|}
\hline 6. & When a customer has a & 2 & 4 & 3.17 & .576
\end{tabular} problem, the staff of your establishment shows a sincere interest in solving it

7. The staff of your establishment provides an agile and timely service.

8. The staff of your establishment provides / concludes its services in the promised time

\begin{tabular}{|l|l|l|l|l|}
\hline 9. The staff of your establishment & 2 & 4 & 3.22 & .736
\end{tabular} informs the client of the characteristics of the product or service that you are receiving

Table 6 Descriptive statistics regarding the reliability dimension of the quality variable

The smallest dispersion in the opinions of the respondents was obtained by the "guarantee" dimension, which indicates that in general the personnel of the participating companies transmit confidence to the clients, inspiring safety (Table 7).

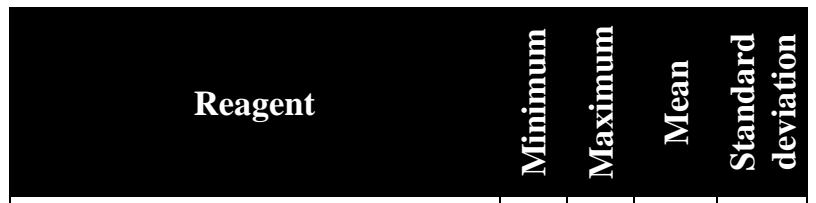

\begin{tabular}{|l|l|l|l|l|}
\hline 13. The staff of your establishment & 2 & 4 & 3.13 & .458 \\
\hline
\end{tabular} inspires / transmits trust to customers

\begin{tabular}{|llll|l|l|l|l|}
\hline $14 . \quad$ Customers of your & 2 & 4 & 3.30 & .635 \\
\hline
\end{tabular} establishment feel safe in their facilities

\begin{tabular}{|l|l|l|l|l|l|}
\hline 15. The staff of your establishment & 3 & 4 & 3.52 & .511 \\
\hline
\end{tabular} is always friendly with customers

Table 7 Descriptive statistics regarding the guarantee dimension of the quality variable 
To assess whether sociodemographic and business factors affect the variables, the Student's T test was determined for independent tests (gender and marital status), and the ANOVA to determine the most relevant differences between variances of the values grouped into ranges; In both procedures, no statistical differences were identified for the leadership variable. In the case of the quality variable when analyzing gender, significant differences were obtained in the "guarantee" dimension, which allows us to infer that this factor affects subjective aspects such as customer trust towards staff, according to the opinion expressed by the management; Similarly, the "tangibility" dimension reported differences in assessing the type of school where the last studies were conducted, whether public or private, as well as the seniority of the manager in the position and the number of employees of the organization, which may originate of the experience acquired when performing the duties of the position; In the case of the number of workers who collaborate in the company and the type of school, it is inferred that this element of the administrative profile affects the decision to participate in courses of non-governmental instances, organize formal training for employees, share project information and in the hiring of specialized personnel.

On the other hand, the "response capacity" dimension presented statistical differences with respect to the age factor, which represents an important aspect to evaluate, since according to management's opinion it can affect the moment of carrying out operations without errors or availability to resolve customer questions from other contributors.

With the quantitative values obtained from the instrument, indices were designed that make it easier to interpret the perception that the management body has regarding leadership and the quality of the services offered; They were called Leadership Index (LI) and Quality Index (CI) which were determined by expressing in percentage the ratio of the division of the individual scores of each company between the maximum value that could be obtained according to the number of reagents of each instrument. A higher value of LI and IC means that the manager has a better perspective of leadership and its impact on the quality of services provided by hotels, (Table 8 ).

\begin{tabular}{|c|c|c|c|c|c|c|}
\hline \multirow[b]{2}{*}{ 老 } & \multicolumn{3}{|c|}{ Leadership Index } & \multicolumn{3}{|c|}{ Quality Index } \\
\hline & 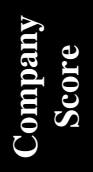 & 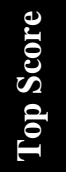 & $\begin{array}{c}\text { LI } \\
(\%)\end{array}$ & 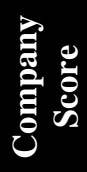 & 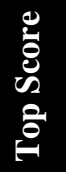 & $\begin{array}{l}\text { IC } \\
(\%)\end{array}$ \\
\hline 1 & 22 & 44 & 50.00 & 43 & 72 & 56.40 \\
\hline 2 & 20 & 44 & 45.45 & 64 & 72 & 55.81 \\
\hline 3 & 31 & 44 & 70.45 & 48 & 72 & 47.09 \\
\hline 4 & 41 & 44 & 93.18 & 66 & 72 & 81.98 \\
\hline 5 & 41 & 44 & 93.18 & 64 & 72 & 83.14 \\
\hline 6 & 38 & 44 & 86.36 & 67 & 72 & 86.63 \\
\hline 7 & 31 & 44 & 70.45 & 53 & 72 & 69.77 \\
\hline 8 & 40 & 44 & 90.91 & 69 & 72 & 94.19 \\
\hline 9 & 36 & 44 & 81.82 & 64 & 72 & 59.88 \\
\hline 10 & 31 & 44 & 70.45 & 54 & 72 & 67.44 \\
\hline 11 & 42 & 44 & 95.45 & 60 & 72 & 86.63 \\
\hline 12 & 22 & 44 & 50.00 & 62 & 72 & 56.40 \\
\hline 13 & 28 & 44 & 63.64 & 51 & 72 & 60.47 \\
\hline 14 & 26 & 44 & 59.09 & 57 & 72 & 69.77 \\
\hline 15 & 26 & 44 & 59.09 & 57 & 72 & 69.77 \\
\hline 16 & 30 & 44 & 68.18 & 53 & 72 & 57.56 \\
\hline 17 & 32 & 44 & 72.73 & 54 & 72 & 58.14 \\
\hline 18 & 27 & 44 & 61.36 & 54 & 72 & 58.14 \\
\hline 19 & 24 & 44 & 54.55 & 50 & 72 & 45.93 \\
\hline 20 & 24 & 44 & 54.55 & 48 & 72 & 45.93 \\
\hline 21 & 11 & 44 & 25.00 & 48 & 72 & 31.98 \\
\hline 22 & 31 & 44 & 70.45 & 54 & 72 & 43.02 \\
\hline 23 & 31 & 44 & 70.45 & 50 & 72 & 43.02 \\
\hline
\end{tabular}

LI = Leadership Index = Maximum Score / Score $\mathrm{x}$ 100. The result can be interpreted as the manager's perception of the leadership present in the organization.

$\mathrm{CI}=$ Quality Index = Maximum Score / Score x 100. The result obtained for each company is the manager's perception of the services offered and the quality of the company.

Table 8 Leadership Index (LI) and Quality Index (CI) Source: self made

According to the results of Table 8, the LI average is 67.68 and reflects the need to formally share the mission and vision for the achievement of long-term business objectives; the average obtained from the CI of the population studied is 62.13 , which gives an idea of the opinion that managers have regarding the quality of their services, and that contrary to what one might think they do not consider them to be adequate.

The results of Table 8 were compared to study the relationship between managers' perception regarding the incidence of leadership in the quality of services provided by each organization and assess whether there is a correlation between the variables, through regression analysis. 
Linear Pearson coefficient was determined $(r=0.75400)$ and the determination coefficient ( $\mathrm{r} 2=56.8 \%$ ), which was obtained by squareing the previously obtained value of the Pearson coefficient. (Lind, Marchal and Wathen, 2012).

\section{Conclusions}

\section{Discussion of results}

From the evaluation of the sociodemographic factors it was observed that gender affects the levels of trust between the client and the staff, as well as the type of school either public or private where the last degree of studies was taken, which is reflected in the aspects of security, priceservice relationship and availability of services. Of the elements related to the administrative profile, seniority in the position and the number of employees who collaborate in the company offers differences in the population studied, which coincides with the restrictions identified by Gutiérrez and Rubio (2009), when it is intended to implement systems of quality management, where constituting the direction by young professionals favors its development as an enabling factor. The leadership identified in the analysis units is the transformational type, where the leader promotes individual and collective negotiation processes with the work teams, which allows to guide creativity in the members of the entity and coincides with that indicated by Turbay (2013).

It highlights that the lowest values were assigned to the way the leader solves the problems, since the market requires changing organizations as Estrada (2006) points out, where the leader with qualities, skills and attitudes facilitates conflict resolution. It is observed that the means obtained as a whole for the quality dimensions will not be considered high since their average value ranges from three, the dimension with the lowest value being tangible, which indicates that infrastructure investment is not sufficient for standards that national and foreign guests demand according to the opinion of the managers of the organizations participating in the study, which is in contrast to what was suggested by Ibañez (2011), who points out that the image of tourism companies as a whole raises their level of occupation and competitiveness, therefore, it is desirable to assess whether the physical investment made to date is adequate according to service standards.
On the contrary, the dimension called guarantee reached the average with the highest average, which indicates that employees are friendly to customers and generates a climate of trust and security, which confirms that the human factor is a fundamental element in the Quality management, and should be involved in the service delivery processes. The above is necessary to achieve customer loyalty and satisfaction, (Gutiérrez and Rubio, 2009).

Reliability is the dimension with the greatest dispersion in the responses expressed by managers, which indicates that the opinions do not coincide in the level of commitment of the other collaborators to solve the possible problems that guests have, it is desirable to encourage the provision of services based in values, norms and practices tending to satisfy the expectations of the client, (Reyes et. al, 2015). On the other hand, there is a coincidence in the managerial opinion regarding the kindness with which employees treat customers, which can be reinforced through training schemes and measuring their performance based on competencies and thus have a better profile design (Guerra and Cardozo, 2010).

\section{Conclusions}

The first objective of the investigation establishes the identification of the quality dimensions from the point of view of the managers of the participating companies who assign an average value of $62.13 \%$, an unexpected situation, since the managers being employed are also responsible for the operation of the hotels and they are aware of the need to raise their quality, therefore, it is desirable to analyze current processes and propose quality management strategies that meet customer expectations.

The next objective is to identify the leadership style present in the hotels, being the transformational one, although the person responsible for guiding these companies in the long term should intervene with opportunity in solving problems, and make decisions whose results raise the positive perception of its management in favor of business goals which was ratified with the leadership index. 
Finally, it was observed that there is a relationship between the variables studied and it can be inferred that the implicit quality of the services offered depends on the way in which the organizations are managed and made decisions.

This research has as a limitation the number of participating companies and the personnel surveyed, developing similar studies in other regions of the country can help establish internal and external factors that affect the level of quality of services offered by companies in the hotel sector and which is reflected in the levels of occupation and competitiveness within the market.

\section{References}

Barreto, A. y Azeglio, A. (2013). La problemática de la gestión del capital humano en las mipymes de alojamiento turístico de la ciudad de Buenos Aires, Argentina. Estudios y Perspectivas del Turismo. pp. 1140-1159.

Contreras F. y Barbosa D. (2013). Del liderazgo transaccional al liderazgo transformacional: implicaciones para el cambio organizacional. Revista Virtual Universidad Católica del Norte. 39 pp. 152-164.

Díaz, J., Medina, J. y de la Garza M. (2011). El liderazgo en las empresas para la obtención de ventaja competitiva en pymes turísticas del sur de Tamaulipas. Memorias de la Red Internacional de Investigadores en Competitividad. Recuperado de www.riico.net.

Estrada S. (2006). Modelo de liderazgo en organizaciones cambiantes. Scientia Et Technica. XII, 32 pp. 295-300.

Foronda, C. y García, A. (2009). La apuesta por la calidad como elemento diferenciador en los destinos turísticos: planes renovados. Cuadernos de Turismo. 23 pp. 89-110.

Fuentes, M., Hernández E. y Morini, S. (2016). $\mathrm{Q}$ de calidad y satisfacción del turista en el sector hotelero español. Cuadernos de Turismo. 37 pp. 203-226.

Guerra, K. y Cardozo, N. (2010). La gestión por competencias. una herramienta para garantizar la calidad del servicio. caso de estudio posadas turísticas del estado Táchira. Provincia. 24 pp. 31-51.
Gobierno del Estado de Campeche (2016). Plan Estatal de Desarrollo 2015-2021. Recuperado el 10 de marzo de 2016 en www.campeche.gob.mx

Gobierno Federal de los Estados Unidos Mexicanos, Presidencia de la República. (2016). Plan Nacional de Desarrollo 2013-2018. México. Recuperado de: www.presidencia.gob.mx

Gutiérrez, S. y Rubio, M. (2009). El factor humano en los sistemas de gestión de calidad del servicio: un cambio de cultura en las empresas turísticas. Cuadernos de Turismo. 23 pp. 129147.

Hernández, R., Fernández, C. y Baptista, P. (2016). Metodología de la investigación. Mc Graw Hill, México

Ibáñez, R. (2011). Diagnóstico de la calidad y competitividad del sector turístico en México. Cuadernos de turismo. 28 pp. 121-143.

Kerlinger, F.N. (2002). Investigación del comportamiento. México: McGraw-Hill

Lind D., Marchal W. y Wathen S. (2012). Estadística aplicada a los negocios y la economía. México: Mc. Graw Hill.

Meira, A. y Rojas, A. (2014). Análisis bibliométrico de la producción científica de 2002 a 2012 sobre calidad en servicios turísticos. Estudios y Perspectivas en Turismo.23. 04 pp. 645-667.

Mul, J., Mercado, L. y Ojeda, R. (2013). Propuesta de un instrumento para conocer las actividades de gestión del conocimiento y los factores organizativos que la influyen. Memorias en extenso del XVIII Congreso Internacional de Contaduría Administración e Informática, UNAM, México.

Parasuraman, A.; Zeithaml, V. y Berry, L. (1985). Servqual: a multiple ítem scale for measuring consumer perceptions of service quality. Journal of Retailing. 6.1. pp. 12-40.

Quijano R., Arguelles L. Fajardo M. (2016). Autoevaluación de prácticas de liderazgo en mipymes turísticas de Campeche, México. Revista de Estrategias del Desarrollo Empresarial. 2, 6 pp. 56-70. 
Reyes, D., Guzmán, D. y Morales A. (2015). Diagnóstico de la calidad de los servicios de hospedaje en Acapulco, Guerrero. Revista Mexicana de Ciencias Agrícolas. 01 pp. 391393.

Secretaría de Turismo (2019). Sistema Nacional de Información Estadística y Geográfica de Turismo. Recuperado de www.datatur.sectur.gob.mx/SitePages/Resultad osITET.aspx

Turbay M. (2013). Liderazgo e innovación organizacional. Psicología desde el Caribe. 30, 1 pp. vii-ix

Velázquez, G. (2005). Liderazgo empático, un modelo de liderazgo para las organizaciones mexicanas. Revista del Centro de Investigación. pp. $81-100$

Zayas, M. (2011). El desempeño, el liderazgo y las competencias en los directivos del sector turístico. Revista de Investigación en Turismo y Desarrollo Local. 4,11 pp. 1-11 